Division of Geological \& Geophysical Surveys

MISCELLANEOUS PUBLICATION 147C

\title{
ANNOTATED BIBLIOGRAPHY SERIES IN SUPPORT OF COASTAL COMMUNITY HAZARD PLANNING-NORTHWEST ALASKA
}

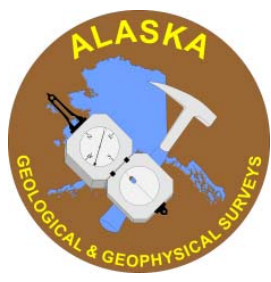

\section{DEERING, ALASKA}

Prepared by Jacquelyn Smith and Nicole Kinsman

November 2011

This annotated bibliography is part of a series created to facilitate access to documents useful for coastal geohazard evaluation and community planning in Northwest Alaska. Below is a comprehensive list of community-specific information sources, each with full bibliographic information and an informative-style annotation that highlights content pertaining to the community of Deering, Alaska. For a detailed description of the preparation and scope of this resource, please refer to this bibliography series' foreword. Any notable errors and/or omissions may be reported to the Coastal Hazards Program manager at the Alaska Division of Geological \& Geophysical Surveys (DGGS).

Alaska Department of Commerce, Community \& Economic Development (DCCED), accessed 2011, Division of Community \& Regional Affairs (DCRA) Community Profiles [website]: State of Alaska Department of Commerce, Community \& Economic Development.

http://www.commerce.state.ak.us/dca/profiles/profile-maps.htm

This website provides access to community profile maps for community-based planning. The maps are available in 24" by 36" and 30" by 42" formats. The Deering maps were created in 1997 based on land surveys and/or interpretation of aerial imagery. Subsistence hunting grounds, habitat areas, community buildings and public facilities are delineated. Shoreline position and potential erosion zones are included in the map content. All maps have been sponsored by the Alaska Division of Community \& Regional Affairs and contracted to local agencies for production.

Elswick, Virginia L., 2003, Seismic interpretation and structural evaluation of the Hope Basin, Alaska [MS Thesis]: Morgantown, WV, West Virginia University Department of Geology and Geography, 21 p.

This MS thesis was submitted to the Eberly College of Arts and Sciences at West Virginia University. The content outlines the geologic setting and history for the Hope Basin, in the Chukchi Sea off the northwestern coast of Alaska. The lithology of Hope Basin was inferred from data collected in two wells drilled at Nimiuk Point on the Seward Peninsula and Cape Espenberg in the Selawik Basin, as well as from seismic data collected by the U.S. Geological Survey in 1977-1980. Four stratigraphic units are described for the area and a structural hypothesis for basin development is presented.

Fair, Susan, W., 1997, Inupiat naming and community history, the Tapqaq and Saniniq Coasts near Shishmaref, Alaska: Professional Geographer, vol. 49, no. 4, p. 466-480.

This publication focuses on the geography and traditional place names in the Shishmaref and Deering area. Included in this work is a description of the regional context with extensive documentation of local knowledge and Inupiat words for common coastal terms such as 'tapqaq' (sandy strand) and 'undani' (downcoast).

Gorokhovich, Yuri, and Anthony Leiserowiz, 2011, Historical and future coastal changes in Northwest Alaska: Journal of Coastal Research, vol. 28, no. 1A, p. 174-186.

This article presents research sponsored by the National Oceanic and Atmospheric Administration (NOAA) in support of coastal vulnerability mapping for Kotzebue Sound, Alaska. The authors used the digital shoreline analysis system (DSAS) to quantify rates of erosion and accretion from orthorectified aerial imagery that spans 
a 53-year period (1950-2003). By combining the results of this work with modeled projections of sea-level rise in the arctic, the authors estimate mean regional erosion rates of -0.12 to $-0.08 \mathrm{~m} / \mathrm{yr}$ from 1950-2003, and an increase to $0.6-1.65 \mathrm{~m} / \mathrm{yr}$ from $2000-2100$.

Hamilton, Thomas D., and Julie Brigham-Grette, 1991, The last interglaciation in Alaska—Stratigraphy and paleoecology of potential sites: Quaternary International, vol. 10-12, p. 49-71.

The authors of this paper identify 20 sites in Alaska where deposits from the last interglacial maximum have been reported. The sites represent a wide range of geologic environments throughout the state. Deering is included as a location where fossiliferous Pelukian deposits have been observed, mostly in the form of broad ridges or raised surfaces at the inland extent of modern beaches. The fossil assemblage at this location is evidence of warmer offshore waters and an absence of sea ice during the interglacial.

Hartig, Larry, of Alaska Department of Environmental Conservation \& Governor's Climate Change Sub-Cabinet, October 2010, State of Alaska and State/Federal Executive Roundtable Activities Regarding the Arctic [presentation]: Anchorage, AK, Northern Waters Task Force, 53 p.

http://housemajority.org/coms/anw/pdfs/26/NWTF_Powerpoint_Hartig_01Oct10.pdf

This is a powerpoint presentation about the state and federal executive roundtable activities regarding the Arctic. The discussion includes hazards associated with declining Arctic sea ice extent, melting of permafrost, storm surges, and coastal erosion. Thirty-one villages are identified as imminently threatened: Barrow, Kivalina, Selawik, Allakaket, Hughes, Huslia, Shishmaref, Deering, Teller, Koyukuk, Nulato, Golovin, Shaktoolik, Unalakleet, Saint Michael, Kotlik, McGrath, Emmonak, Alakanuk, Chevak, Newtok, Nunapitchuk, Lime Village, Eyak (Cordova), Napakiak, Akiak, Chefornak, Kwigillingok, Dillingham, Clark's Point, and Port Heiden. Specific photos and engineering initiatives for four communities are discussed, including: Kivalina, Shishmaref, Unalakleet, and Newtok.

Immediate Action Workgroup (IAWG), Michael Black and Patricia Opheen, eds., March 2009, Recommendations to the Governor's Subcabinet on climate change: Immediate Action Workgroup, $162 \mathrm{p}$.

The Immediate Action Workgroup was established to address known threats to Alaskan communities caused by coastal erosion, thawing permafrost, flooding and fires. This report is a follow-up to the recommendations made in April 2008 (in which Deering was not mentioned), and provides recommendations for actions and policies to be implemented in 2009 and 2010 regarding these matters. The community of Deering has been recognized as receiving agency actions from the U.S. Army Corps of Engineers and the Department of Commerce, Community \& Economic Development.

Kneeland, Patrick, Colin Phillips, and Doug Jerolmack, 2011, Coastal erosion on the Baldwin Peninsula in arctic Alaska [poster]: University of Pennsylvania, Environmental Studies.

http://www.sas.upenn.edu/earth/PatrickKneeland.jpg

This is a poster available online describing coastal erosion research conducted on the Baldwin Peninsula in Kotzebue Sound. Individual erosion hot spots, surveyed in 2009, are analyzed for possible modes of erosion. The potential impacts of erosion within the region are briefly discussed and the trends are interpreted through the context of global climate change.

Mason, Owen K., and James W. Jordan, 2002, Minimal late Holocene sea level rise in the Chukchi Sea-Arctic insensitivity to global change?: Global and Planetary Changes, vol. 32, p. 13-23.

In this article, Mason and Jordan outline the apparent disconnect between late Holocene global sea level rise and the moderate sea level rise observed in Northwest Alaska. Radiocarbon ages taken from peat and storm deposits in Seward Peninsula lagoons allowed for the reconstruction of a sea level curve spanning the last 6,000 years. The results indicate that sea level in northwestern Alaska has risen an average $0.3 \mathrm{~mm}$ per year compared to the global average of 1-2 $\mathrm{mm}$ per year. The authors suggest several hypotheses for these differing rates including cold sea surface temperatures (limited steric expansion), geoid variation and/or the development of permafrost. Although observed rates of sea level rise are moderate for the Chukchi Sea, the article cautions that the response of northern Alaska's coasts to future global climate change remains uncertain and requires continued investigation. 
Matthews, J.V., Jr., September 1974, Quaternary environments at Cape Deceit (Seward Peninsula, Alaska)— Evolution of a tundra ecosystem: Geological Society of America Bulletin, vol. 85, no. 9, p. 1353-1384.

This paper discusses the Quaternary environment of Cape Deceit, Alaska, adjacent to the community of Deering. Analyses were conducted based on exposed, unconsolidated sediments containing pollen and biotic fossils. By interpreting samples from the stratigraphy, a chronology of tundra evolution was constructed. The chronology suggests that since the last glaciation the area has undergone former periods of warmer climate with less tree cover.

McCulloch, David S., Dwight W. Taylor, and Meyer Rubin, 1965, Stratigraphy, non-marine mollusks, and radiometric dates from Quaternary deposits in the Kotzebue Sound area, western Alaska: The Journal of Geology, vol. 73, p. 442-453.

This article provides detailed information and ages of Quaternary stratigraphic units in Kotzebue Sound spanning multiple marine transgressions and glaciations. The defined units are based on analysis of fossil assemblages exposed in the coastal bluff environment that are consistently observed in the regional stratigraphy. Units were assigned ages based on mollusk samples collected from the Baldwin Peninsula and Kobuk River.

Olson, Neil F., and Ben T. Crosby, 2007, Digital mapping of coastal erosion on the Baldwin Peninsula, Northwest Alaska_-Past rates, current processes and future implications [abs. \& poster]: American Geophysical Union Transactions Fall Meeting Supplement, vol.88, no. 52, Abstract GC33A-0962.

http://geology.isu.edu/ crosby/research/pubs_posters/Olson_Crosby_Baldwiin_Peninsula_Erosion_AGU_2007.pdf

This poster presents research conducted on the Baldwin Peninsula, Alaska. High-resolution topographic surveys, field observations, and interpretation of aerial imagery were used to determine erosion rates and mechanisms at the narrowest point on the peninsula and to provide a baseline for future measurements. The motivation for conducting this research was to address concern about a potential breach of a narrow (700 m) portion of the peninsula, which would have significant navigation and ecological implications for the area.

Péwé, Troy L., David M. Hopkins, and Arthur H. Lachenbruch of U.S. Geological Survey for U.S. Atomic Energy Commission, April 1958, Engineering geology bearing on harbor site selection along the northwest coast of Alaska from Nome to Point Barrow: U.S. Geological Survey (USGS) Trace Elements Investigations report no. 678, $57 \mathrm{p}$.

This report provides geologic and oceanographic information from previous investigations, aerial imagery, and reconnaissance field work regarding the optimal location of a deep-water harbor. The harbor was to be constructed using modern nuclear explosives and located at a point along the northwest coast of Alaska between Nome and Point Barrow. The project was not undertaken.

Pungowiyi, Caleb; Henry P. Huntington, ed., 2000, Native observations of change in the marine environment of the Bering Strait region, in Impacts of Changes in Sea Ice and Other Environmental Parameters in the Arctic, Final Report of the Marine Mammal Commission Workshop, Girdwood, Alaska, 15-17 February: Bethesda, MD, Marine Mammal Commission, p. 26-29.

http://www.mmc.gov/reports/workshop/pdf/seaicereport.pdf

The purpose of the Marine Mammal Commission Workshop was to bring together scientists and indigenous experts to discuss the changes in mammalian populations throughout Alaska. Observed fluctuations in sea ice and other environmental parameters were reported throughout all of Kotzebue Sound. In Deering, changes in ice thickness have limited the community's ability to hunt for bearded seal. There were also reported sightings of never-before-seen species of whales and dolphins near Deering. Changes in terrestrial mammal populations are also discussed in this document.

Rural Alaska Mitigation Planning (RAMP), Missal, LLC for Northwest Arctic Borough, March 2009, Northwest Arctic Borough multi-jurisdictional all-hazard mitigation plan: Northwest Arctic Borough, 166 p.

This plan was developed to help the Northwest Arctic Borough make decisions regarding natural hazards affecting its communities and to fulfill requirements of the Disaster Mitigation Act and the National Flood Insurance Reform Act for future grant funding. The region is separated by community and delineated for hazard 
type and hazard probability. The main hazards identified and described for Deering are erosion, flooding, and severe weather.

Simpson, J.J., January 1984, Final Report, Task Force on Erosion Control: Alaska Department of Transportation \& Public Facilities, project no. R-30023, 101 p.

The Erosion Control Task Force was appointed to investigate and inventory potential erosion problems on a statewide basis, to prioritize the erosion problem sites by severity and need, and to provide preliminary design plans where immediate remedial action is required. Sites were rated based on public safety, public property, private property, time of projected loss, ability to move, approximate replacement value, and economic value. Projected costs of erosion protection measures were analyzed, totaling $\$ 16,802,300$ for all projects. This report outlines specific engineering projects to reduce the effects of coastal and riverine erosion for communities throughout Alaska.

The destruction of beach grass in Deering makes the use of fuel drums, gabion baskets, or coarse rock a poor method of preventing erosion. The report suggests using natural material from the area in the original beach slope angle for erosion protection. The sand spit, however, will remain vulnerable to flooding during major storms of about ten year frequency.

Taylor, Ronald J., 1981, Shoreline vegetation of the arctic Alaska coast: Arctic, vol. 34, no. 1, p. 37-42.

This study was administered by the Outer Continental Shelf Environmental Assessment Program (OCSEAP). The primary objective of this work is to provide descriptions and definitions of vascular beach plants along the arctic coast of Alaska in order to better predict the effects of oil spills on the region's ecosystems. Deering was used as a research station representative of a coastal-bluff-dominated habitat. This environment was associated with high rates of coastal erosion, low vegetative cover, and a poorly defined plant community assemblage.

Tetra Tech for Immediate Action Workgroup: Advisory group of the Governor's Climate Change Sub-Cabinet, June 2010, Imperiled community water resources analysis: Anchorage, Alaska, Tetra Tech, 47 p.

This report summarizes climate-related threats to water and wastewater infrastructure within Alaskan communities including those at risk of flooding, saltwater intrusion, loss of surface water supply, erosion, and sedimentation of the source region. The primary objectives of the analysis were to:

1. Identify and select study group communities whose water infrastructure is threatened

2. Collect information on the threatened water infrastructure for the study group communities

3. Analyze information to determine the climate-related impacts to study group community water infrastructure. (p. 2)

Deering is included in the study group as an example of a low-lying coastal community that is influenced by the "lack of sea ice and timing of sea ice" and the "increased effects of storm surges unbuffered by shorefast ice." The water infrastructure identified as at risk includes the sewage lagoon and the main water line. Both are located near the shoreline and at risk to coastal and riverine erosion. A general community profile is available within the report that outlines the socioeconomic, geologic and climatic setting, provides an overview of the existing water resources and summarizes a brief history of documented historical impacts to existing water infrastructure.

U.S. Army Corps of Engineers, accessed 2011, Civil works floodplain management services [website]: U.S. Army Corps of Engineers, Alaska District.

http://www.poa.usace.army.mil/en/cw/fld_haz/floodplain_index.htm

This website provides flood hazard data for communities throughout Alaska. A link is provided to a floodhazard-specific bibliography, maintained by the U.S. Army Corps of Engineers. The most recent flood event reported for Deering was in 1990, caused by an ice jam and spring runoff. The worst flood event on record is listed as occurring in 1974 during a fall storm.

U.S. Army Corps of Engineers, March 2009, Study findings and technical report: Alaska baseline erosion assessment: Elmendorf Air Force Base, AK, U.S. Army Corps of Engineers, Alaska District, 68 p.

http://www.poa.usace.army.mil/AKE/Home.html 
This statewide assessment was conducted by the U.S. Army Corps of Engineers to coordinate, plan, and prioritize responses to erosion throughout Alaska. The report designated 26 communities, including Deering, as priority action communities. The Army Corps of Engineers identified Deering as susceptible to coastal and riverine erosion, primarily due to its location on a gravel spit. Erosion response in Deering included a State emergency erosion protection grant in 1995 with a total project cost of \$500,000, as well as the completion of two COE revetments amounting to 1,400 feet of shore protection.

Online access to this document includes a link to Erosion Information Papers specific to each community. These Alaska Village Erosion Technical Assistance Program (AVETA) reports include a description of the community setting, erosion problem, and potential damages as well as historic/predicted shoreline position maps (based on approximated erosion rates) and community-provided photos of erosion.

U.S. Government Accountability Office (GAO), June 2009, Report to congressional requestors-Alaska Native villages, limited progress has been made on relocating villages threatened by flooding and erosion: U.S. General Accountability Office Report GAO-040895T, 53 p.

\section{http://www.gao.gov/products/GAO-09-551}

This report is a follow up to the 2003 GAO report on flooding and erosion in Alaska Native villages, and was completed to identify concerns due to climate change that have increased the urgency of federal and state efforts. The GAO developed recommendations for Congress that include:

1. A flooding assessment to augment the erosion assessment completed by the Army Corps of Engineers.

2. An amendment to federal legislation that would allow 64 more villages to be eligible for grants.

3. The designation of a federal entity to oversee and coordinate village relocation efforts.

This report recognizes Deering as one of 31 villages facing an imminent threat from flooding and erosion.

U.S. Government Accounting Office (GAO), 2003 [2004], Alaska Native villages—Most are affected by flooding and erosion, but few qualify for federal assistance: U.S. General Accounting Office Report GAO-04-142, 82 p.

http://www.gao.gov/products/GAO-04-142

This study was conducted to provide recommendations to Congress that would improve how state and federal agencies respond to flooding and erosion in Alaska. This was done by:

1. Determining the extent to which these villages were affected.

2. Identifying federal and state flooding and erosion programs.

3. Determining the current status of efforts to respond to flooding and erosion in nine villages.

4. Identifying alternatives that Congress may wish to consider when providing assistance for flooding and erosion. (from "Highlights" section)

The recommendations provide alternatives to current actions taken during flooding and erosion responses by including federal agencies and the Denali Commission. The adoption of policies by the Denali Commission would guide investments in infrastructure for Alaska Native villages affected by flooding and erosion. Deering was recognized as one of the 31 Alaska Native Villages facing an imminent threat from flooding and erosion.

Whaley, Frank H., 1960s, Aerial view of Deering, Alaska [photograph]: Anchorage, Alaska, Anchorage Museum at Rasmuson Center, original size 8-1/8" x 10"

http://vilda.alaska.edu/cdm4/item_viewer.php?CISOROOT=/cdmg2\&CISOPTR=4371\&REC=20

This is an archived image in the Anchorage Museum of History and Art, which shows the village of Deering, Alaska. The image allegedly dates from between 1960-1969.

Wise, James L., Albert L. Comiskey, and Richard Becker, 1981, Storm surge climatology and forecasting in Alaska: Anchorage, Alaska, Arctic Environmental Information and Data Center, University of Alaska, 26 p.

The objective of this study was to improve the quality of life and the security of property in coastal areas susceptible to flooding by enhancing the decision-making process for human activities and development. This study compiles historical climate data to develop a surge forecast regression equation. Storm profiles specific to Deering are recorded for 1974 and 1963. 